\title{
Behavioural Complexity and Modern Traits in the Philippine Upper Palaeolithic
}

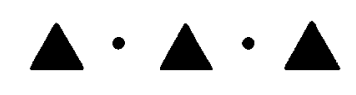

ALFRED F. PAWLIK

\section{INTRODUCTION}

The Discussion of CUltural, COGNitive, AND BeHAVIORAL MODERNity has a long tradition in Europe's prehistoric archaeology (Dibble 1989; Hahn 1986; Jelinek 1982; Klein 1995, 1999; Mellars 1989a, 1989b). The appearance of specialized blade industries, bone and antler tools, and especially figurative art, musical instruments, and personal ornaments are seen as significant indicators of the highly developed cultural and cognitive abilities of their makers (Clottes 2001; Conard 2003; Conard et al. 2004). The seemingly sudden appearance of expressive art and symbolism together with complex tool technologies in Europe at around 40,000 years ago has been attributed to explosive cultural and cognitive advancement with the arrival of anatomically modern Homo sapiens (Klein and Blake 2002; Mellars 1991; Mithen 1996). Whether this Upper Palaeolithic revolution in Europe was due to social factors or genetic mutation, was related to changes in the ecosystem, or has a cultural explanation (such as competition with another human species, the Neanderthals) is still under debate (Bar-Yossef 2002; Conard et al. 2004; D'Errico 2003; Haidle 2006; McBrearty and Brooks 2000; Mellars 2005; Zilhão 2001). Yet, the "human revolution" model is used to explain the success of the Homo sapiens immigrants over the Neanderthals (Bräuer and Smith 1992; Conard 2006, 2008; Mellars 2005).

On the other hand, potential indicators of an earlier and gradually developing cultural and cognitive modernity have been seen in African assemblages. The appearance of some modern cognitive traits (e.g., production of projectile points, shell-fishing, personal ornaments, notational or incised pieces, and pigment processing) in Africa has been dated back to the Middle Pleistocene, earlier than the first evidence of anatomically modern hominids 200,000 years ago (Henshilwood et al. 2002; Johnson and McBrearty 2010; McBrearty and Brooks 2000; McBrearty and Stringer 2007). Consequently, it was assumed that Homo sapiens left Africa and populated the world with an entire package of modern behavioral traits (Klein 2003).

The comparison of the European archaeological record with the African trait list has led to the hypothesis that if all these traits are indeed markers of behavioural modernity, then they might have developed in parallel and independent from species.

Alfred F. Pawlik is an Associate Professor and Scientist I in the Archaeological Studies Program at the University of the Philippines, Quezon City, Philippines. 
Evidence is not only found in the context of anatomically modern humans, but also in association with Neanderthal fossils and Middle Palaeolithic cultural remains, including pigments, notational pieces, personal ornaments and bone tools, grinding stones, composite-tool technology, and synthetically produced birch pitch used as adhesive (Conard 2008; D'Errico 2003; Haidle 2008; Haidle and Pawlik 2010; Henshilwood and Marean 2003; Pawlik and Thissen 2008, 2011). This hypothesis may be relevant to explaining indicators of modernity found in the large and diverse region of Southeast Asia and the Indo-Pacific. However, with the exception of the Sahul region, scholars debating the development of modernity have mostly ignored this part of the world (Brumm and Moore 2005; Habgood and Franklin 2008).

In Southeast Asia, the fossil record suggests the first appearance of modern hominids dates to approximately 50,000-40,000 B.P. (Barker et al. 2007; Détroit et al. 2004; Fox 1978) or even earlier (Mijares et al. 2010). There seems to be a remarkable absence of most of the listed modern traits in the archaeological record. Habgood and Franklin recently stated that a cohesive "package" of cultural innovations did not exist in the Indo-Pacific at the beginning of human expansion into the Sahul region and that modern "components were gradually assembled over a 30,000 year period" (Habgood and Franklin 2008:214). However, the current list of traits used for detecting or refuting the existence of modern human behavior is based on African and European archaeological records. It must be investigated whether this list is valid for Southeast Asia. We may also question whether the occurrence of the entire package is necessary or if the appearance of single traits is sufficient to claim behavioral modernity in Southeast Asia.

\section{THE PHILIPPINE PALAEOLITHIC}

Palaeolithic sites in the Philippines are mainly situated on Palawan Island and Luzon Island (Fig. 1). While it is quite certain that Palawan Island was once connected to Borneo and part of the enlarged landmass of Sundaland during sea-level regressions in the Pleistocene, the possibilities of a connection of Luzon Island with Sundaland are still under discussion. The existence of large land mammals such as Elephas, Stegodon, and Rhinoceros during the Middle Pleistocene has been confirmed by the presence of fossil bones all over the island. These fossils might be an argument for the existence of such a land bridge or at least very close proximity to the mainland (Fig. 2). The land bridge may have allowed mammals to island-hop during glacial periods characterized by shallow waters and emerged islands (Bautista and de Vos 2002; Bondoc 1979; Dizon and Pawlik 2010; Fox 1978; Pawlik and Ronquillo 2003; Piper et al. 2009; Shutler and Mathisen 1979; von Koenigswald 1958).

Fossil hominid remains found in the Philippines have been classified as Homo sapiens (Détroit 2002). Best known is the so-called "Tabon Man" found in the Upper Palaeolithic layers of Tabon Cave at Lipuun Point, Palawan Island (Fig. 3). Actually the remains of several individuals, including a skullcap, two mandible fragments, and several teeth, Tabon Man was found during the excavations conducted by Robert Fox from 1960 until 1967 (Fox 1970). Radiocarbon-dated charcoal from the corresponding layer pointed to an age of approximately 22,000-24,000 B.P. (Fox 1970). Thirty years later, the frontal bone was directly dated by uranium gamma-ray counting at the Institut de Paléontologie humaine of the Muséum national d'Histoire naturelle in Paris and its date corrected to 16,500 \pm 2000 B.P. (Dizon et al. 2002). A human tibia 


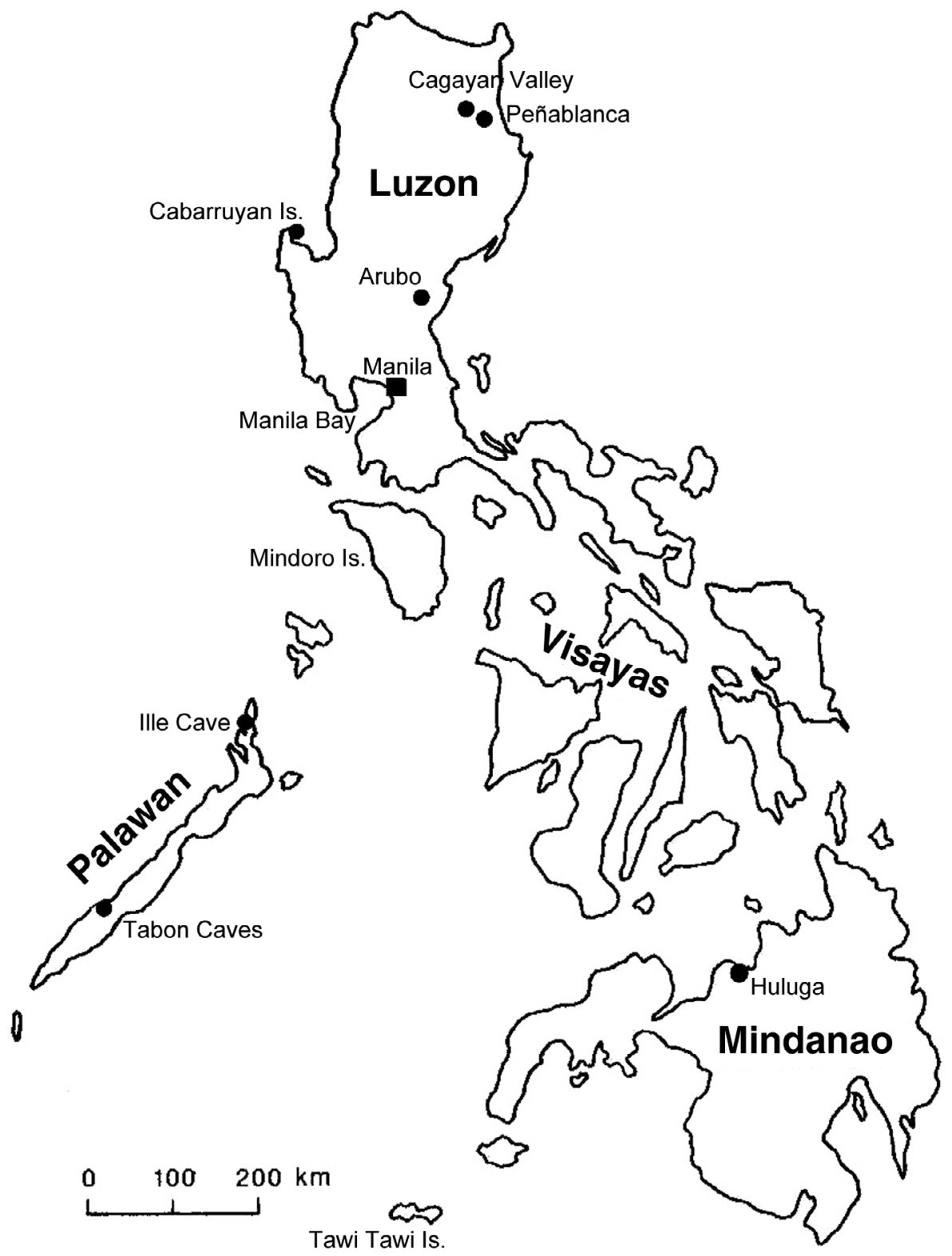

Fig. 1. Map of the Philippines with Palaeolithic sites.

from the lowest archaeological layer excavated during a re-investigation of Tabon Cave by the National Museum of the Philippines and the Institut de Paléontologie humaine, Paris, delivered another uranium series date published as 47,000 +11,000/ $-10,000$ B.P. (Détroit et al. 2004). Although this is consistent with Fox's (1970) estimate of the lowest cultural layer in Tabon Cave dating to 50,000 B.P., the very high standard error of the U-series dates demands a cautionary consideration of the absolute dates from Tabon. 


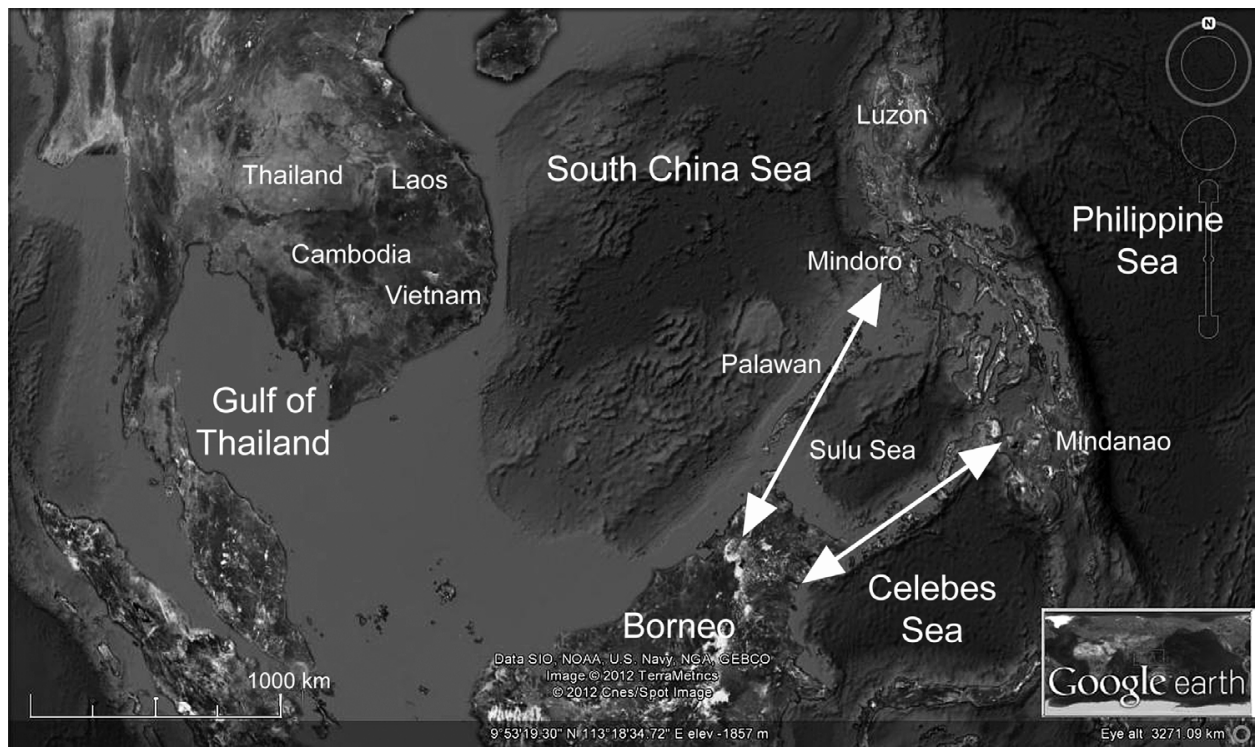

Fig. 2. Sunda shelf and potential migration routes into the Philippine archipelago. (Base map created with Google Earth 7.0)

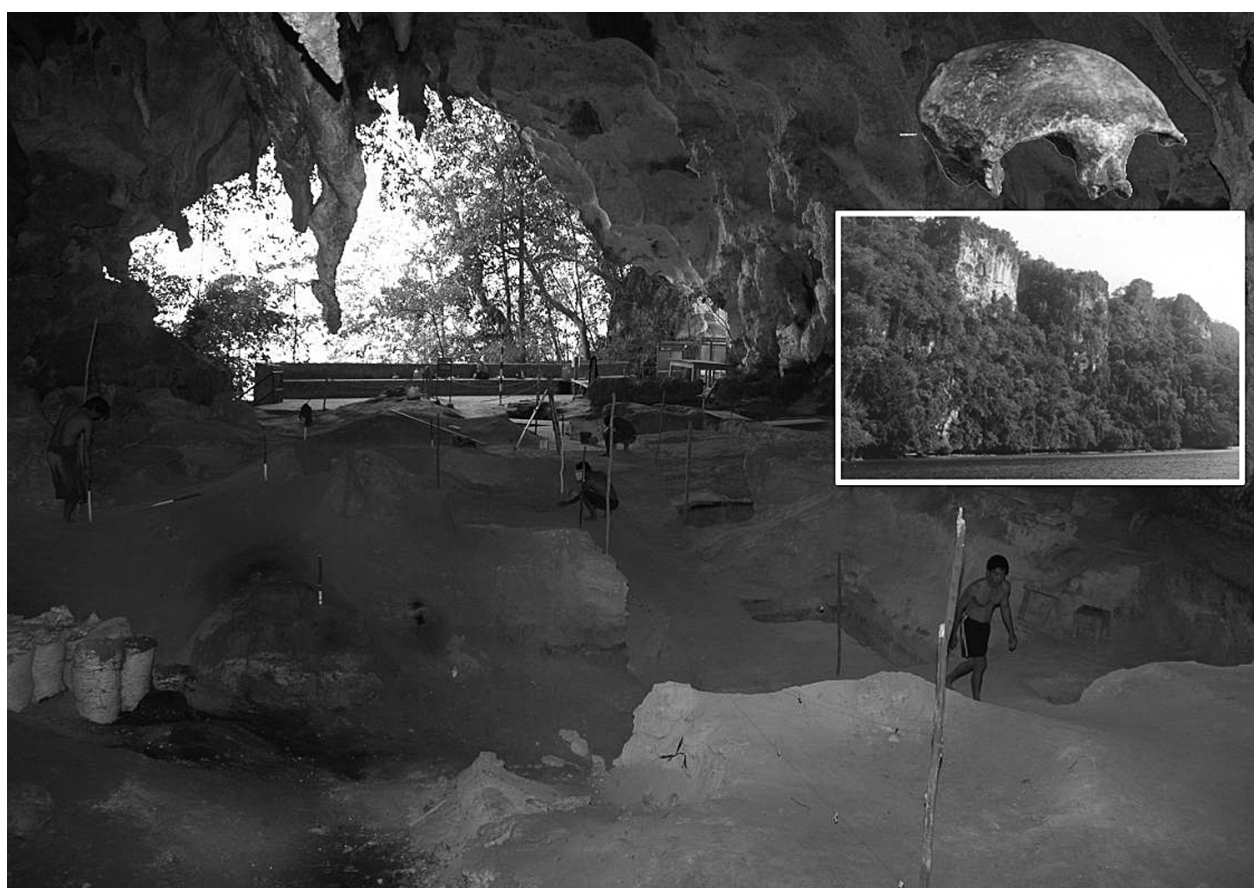

Fig. 3. Excavation of Tabon Cave. Inserted: view of Tabon Rock at Lipuun Point; Tabon Man skullcap (upper right corner). 


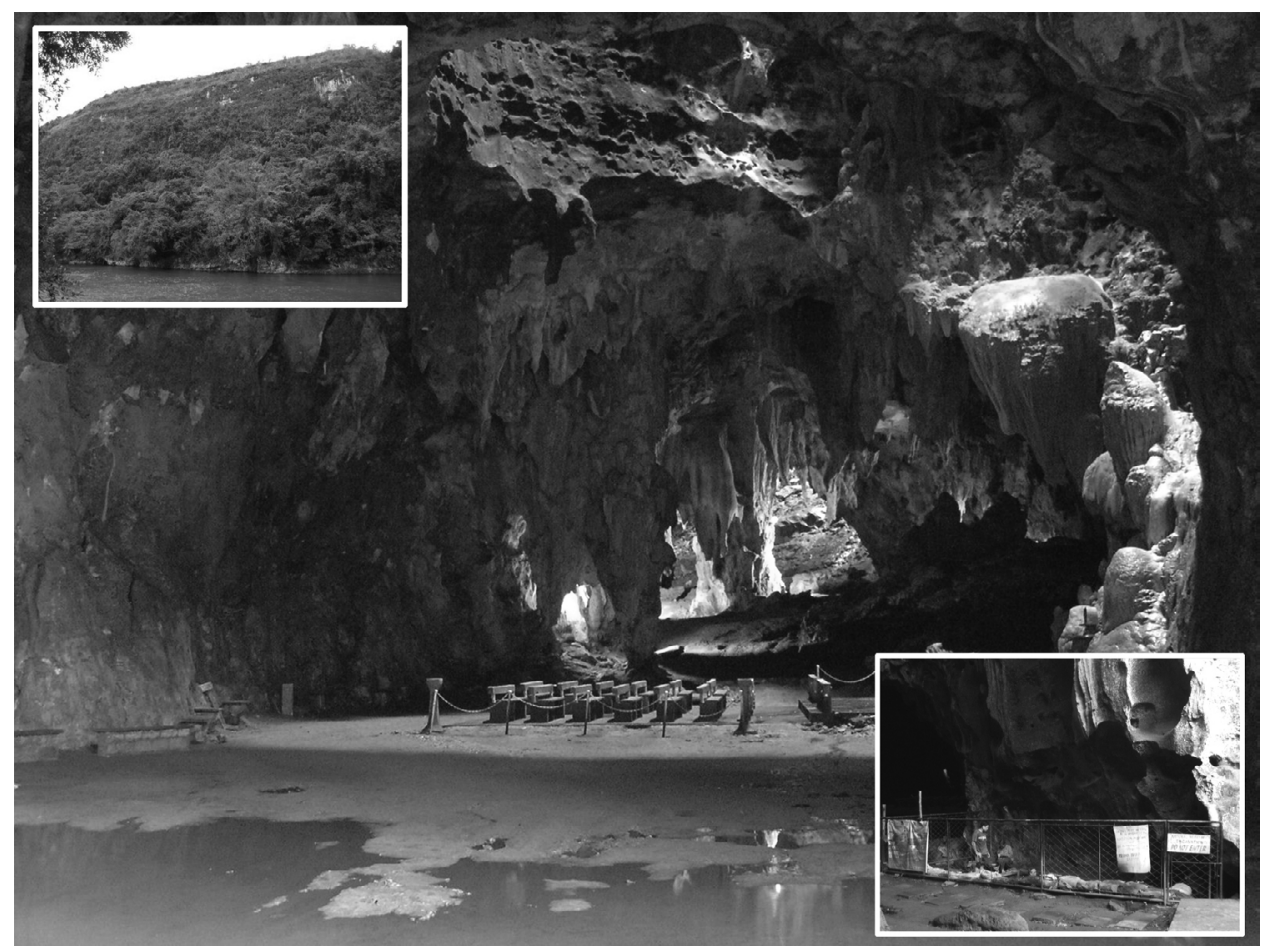

Fig. 4. Callao Cave, Peñablanca. Inserted: the Peñablanca formation (upper left); entrance hall with excavation area (lower right).

In Peñablanca, Cagayan, in the northern part of the Philippines, Upper Pleistocene layers of Callao Cave contained flaked artifacts and charcoal that delivered a radiocarbon date of 25,968 \pm 373 B.P. (Mijares 2008; Fig. 4). Below this, a human third metatarsal bone has been found in a breccia layer; it was dated to $66,700 \pm 1000$ B.P. by laser ablation U-Series (Mijares et al. 2010). This sets the earliest human presence in the Philippines even further back than Tabon Cave. Morphology and size of the foot bone fall within the range of Homo sapiens, Homo habilis, and Homo floresiensis.

\section{ABSENCE OF MODERN TRAITS IN SOUTHEAST ASIA'S PALAEOLITHIC?}

Despite the presence of anatomically modern humans in the Philippines' Upper Pleistocene, possibly up to c. 70,000 years ago, evidence for modern packages in the archaeological record is poor. Very few items from the Afro-European trait list appear in the Philippine Palaeolithic. In particular, its lithic assemblages do not possess a convincing modern character. The general absence of "modern" tool types and formal tools in Southeast Asia's Palaeolithic industries, especially compared with the European lithic records, has been explained as due to the poor availability and difficult acquisition of lithic raw material and a compensatory existence of wooden or bamboo tool industries (Dennell 2009; Mellars 2006; Mijares 2002; Narr 1966; Pope 1989; Schick and Zhuan 1993; Solheim 1970). For taphonomic reasons, such "vegetal industries" remain hypothetical. Tools made of bamboo and wood are not present in 
Pleistocene and early Holocene archaeological assemblages. Furthermore, their production would have required stone tools. The wood/bamboo tool hypothesis neither considers factors of tool mechanics and usage nor deals with the fact that large lithic assemblages are present in the archaeological record. It can certainly be assumed that tools and utilitarian objects were made of vegetal materials including bamboo and wood, but they were more likely an addition to the lithic toolkit than replacements such as the few bone tools found in Southeast Asia (Barton et al. 2009; Pawlik 2009a). Furthermore, the causality of how production of vegetal tools led to simplification of lithic industries has not been convincingly explained. Finally, artifacts made of rocks possessing sufficient knapping quality (i.e., chert or even obsidian) are not uncommon in Southeast Asian sites (Beyer 1947; Charoenwongsa 1988; Mijares 2002, 2004; Moser 2001; Neri 2002, 2005; Pawlik 2002, 2004a; Pookajorn 1988).

Two Upper Palaeolithic/Epipalaeolithic technocomplexes have been morphologically and technologically analyzed and published so far in the Philippines: the socalled Tabonian Industry (Fox 1970; Patole-Edoumba 2002) and the "Peñablanca expedient technology" (Mijares 2002). They are distinguished by their dominant raw material, radiolarian chert for the Tabonian (Schmidt 2008) and andesite at Peñablanca (Mijares 2002). Without any transitional stage, the Tabonian industry suddenly replaces the earlier "Lower Palaeolithic" core tool assemblages with dominantly small-sized flake industries (Pawlik 2009a). Intentional modification of these flakes is rarely observed; edge retouches and alterations are usually caused by use (Fox 1970; Mijares 2004; Ronquillo 1981). A comparison of the Palaeolithic assemblage of Tabon Cave with the lithic materials from several Holocene sites in Palawan, such as the Duyong Cave, Guri Cave, or the Pilanduk rockshelter (Fox 1970, 1978; Kress 1979; Patole-Edoumba 2002, 2009; Tulang 2000), presents a continuation of the Tabonian from the Upper Pleistocene into the Holocene until the early Neolithic (Fig. 5).

More than $1000 \mathrm{~km}$ distant from Tabon, the lithic technology of Peñablanca in northern Luzon is very similar in appearance. The excavation at Callao Cave in the northern part of Luzon Island delivered a small assemblage of flaked artifacts (Fig. 6). The Upper Palaeolithic industry also continues without significant morphological changes into the early Holocene at Callao and several other Epipalaeolithic sites in the same limestone formation at Peñablanca, including Laurente Cave, Minori Cave, Rabel Cave, and others (Mijares 2002; Pawlik and Ronquillo 2003; Ronquillo 1981). In general, the Peñablanca technology is represented by simple flake assemblages without formal elements, dominantly made of andesite and chert. Based on a technological study combined with a microscopic use-wear analysis, these assemblages have been characterized as products of an "expedient technology" where flakes were produced from locally available raw material by direct percussion and without further modification, used for single tasks, and discarded afterwards (Mijares 2002). This interpretation corresponds with recent microwear studies on selected artifacts from Tabon Cave where the limited appearance of microwear traces suggests a similar strategy for the Tabonian industries on Palawan (Mijares 2004; Xhauflair 2009). Also the newly excavated chert assemblage from the Pleistocene layer of Callao Cave fits into an expedient technology tradition in terms of technology and use-wear (Mijares 2008).

Since 1998, the Archaeological Studies Program at the University of the Philippines has been conducting field research in the Dewil Valley in El Nido, northern Palawan Island (Fig. 7). As part of the Palawan Palaeohistory Project, the Ille Cave site 


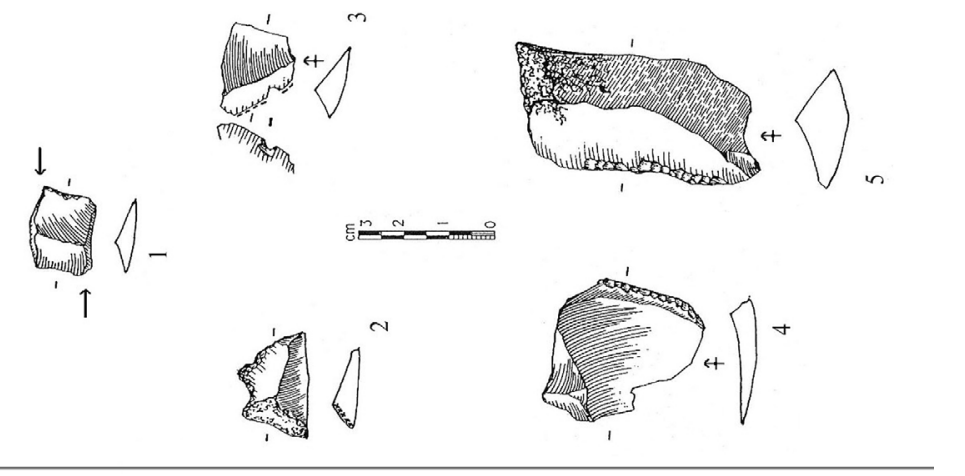

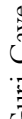

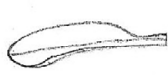

,
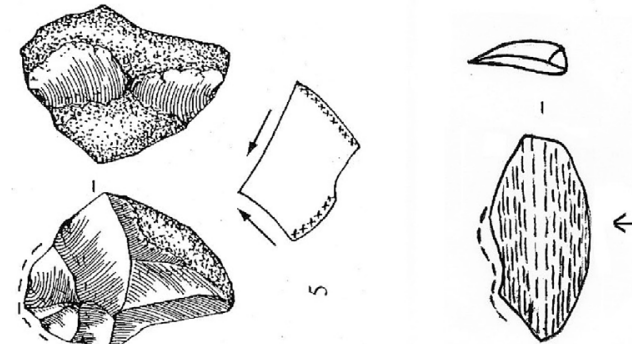

$\Longrightarrow$

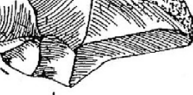

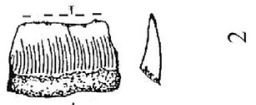
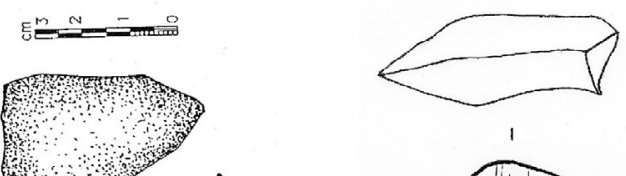

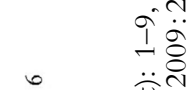
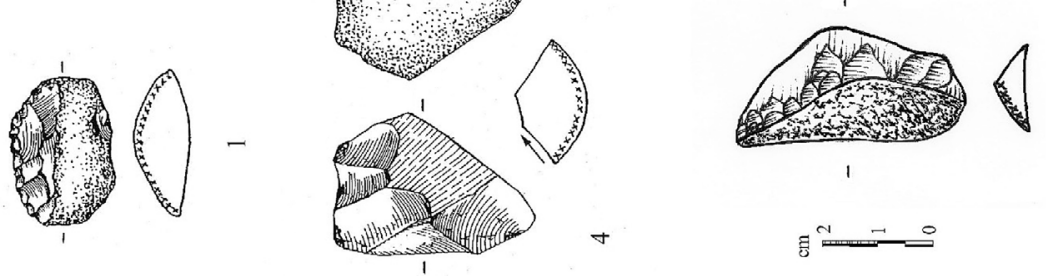

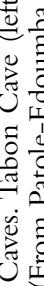

节

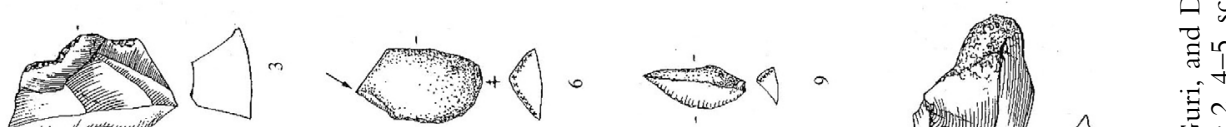

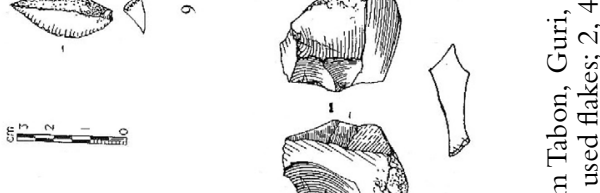

1.

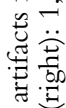

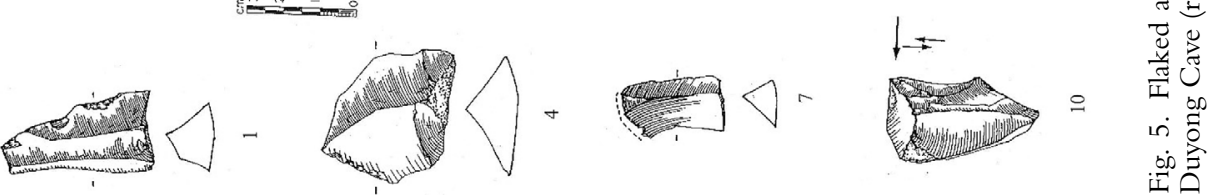




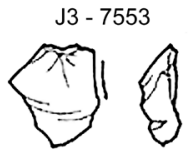

Chert

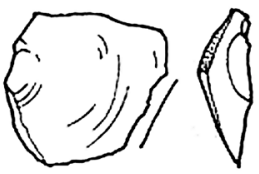

Chert
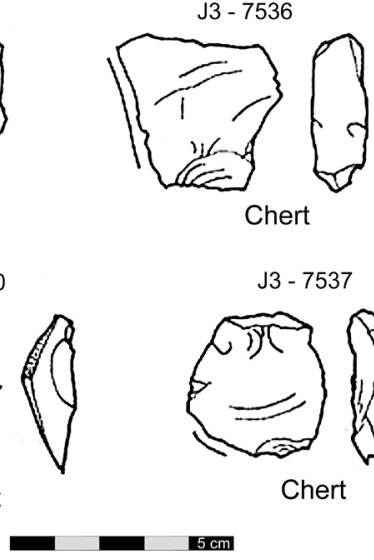

J3 - 7537

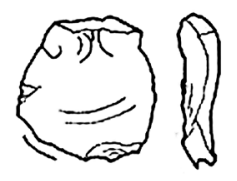

Chert

J3 - 7545
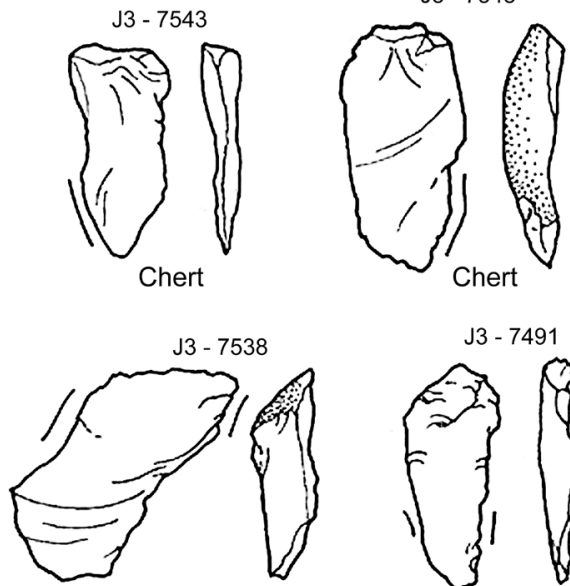

Chert

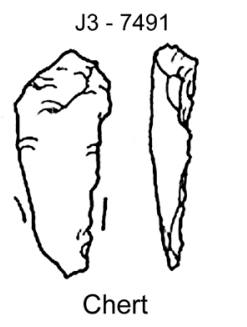

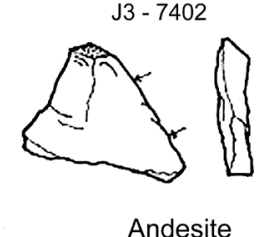

J3 -7401

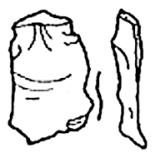

Chert

J3 -7398

$\mathrm{J} 3-7393$
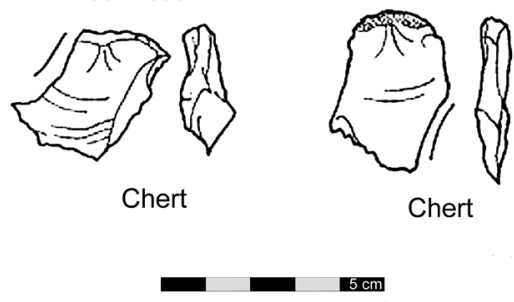

J3 - 7417

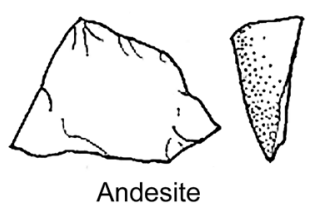

J3 - 7295

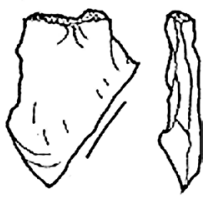

Andesite

Fig. 6. Flaked artifacts from Upper Palaeolithic (left) and Neolithic (right) layers, Callao Cave, Peñablanca. (After Mijares 2005, 2008)

is being excavated by a multinational team of archaeologists, archaeobiologists, and sedimentologists (Archaeological Studies Program 2007; Cayron 1999; Pawlik 2006; Paz et al. 2006, 2008; Szabó et al. 2004).

These excavations have so far presented a cultural sequence down to the Upper Palaeolithic and Pleistocene. From the Neolithic until protohistoric times, the site was also used as a burial ground. Burials and artifacts supply evidence for the intensive use of the Dewil Valley area during the Palaeolithic and Neolithic. A small flake assemblage was recovered from terminal Pleistocene layers (Fig. 8). Radiocarbon dates delivered an age of approximately 14,000 B.P. (Paz et al. 2008). The morphology of the artifacts appears similar to Tabon and Peñablanca, with simple and irregular flakes manufactured by direct percussion and an absence of formal tools (Pawlik 2009b). Likewise, a lack of modern traits is apparent for the Palaeolithic material from Ille Cave and expedient tool use strategies seem obvious. 


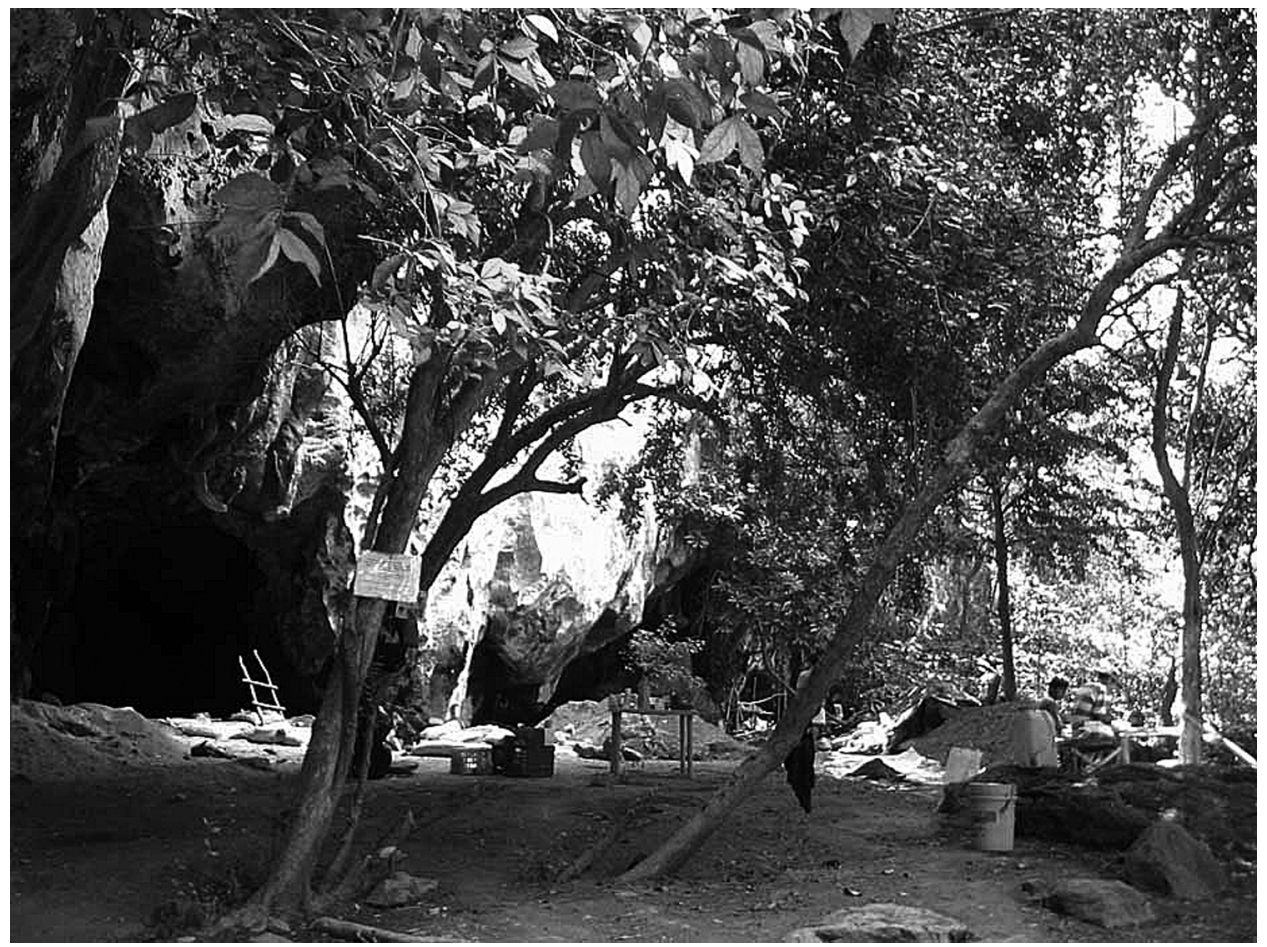

Fig. 7. Ille Cave and cave platform, El Nido, Palawan Island.

If this kind of strategy for lithic tool production and use has to be considered, then it is not surprising that the lithic elements of modern packages are missing in the Philippine Palaeolithic. Expedient technology lacks curation, core preparation, and indirect percussion and therefore does not result in specialized blade production. At best, the microlithic component existed only with regard to size, but no geometric microliths such as those produced in Africa and Europe have been found. Formal tools in general are extremely rare.

The simple and indifferent technology that produced an overall amorphous small flake industry is dominant until the developed Neolithic and the beginning of the "Austronesian expansion" into island Southeast Asia and the Pacific (Bellwood 1997). Non-lithic traits including tools made of bone, antler, or shell, projectile points, figurative art, musical instruments, and personal ornaments are also absent. A few shell artifacts appear in the earlier stages of the Philippine Neolithic, but not before 7,000 B.P. (Ronquillo et al. 1993; Szabó 2005). Although the Philippine Upper Palaeolithic assemblages are certainly associated with modern Homo sapiens since at least about 50,000 years ago, they obviously failed to assemble a distinctive package of modern traits and behaviour. This leaves us with two possibilities: either their cognitive, cultural, and technological behaviour was completely different from modern hominids in Europe and Africa and not "modern" at all or the hypothesis that modern behaviour coincides with the assembling of a particular "modern package" has to be reconsidered. 


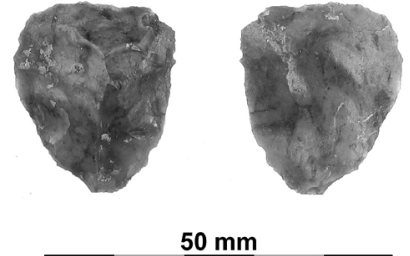

$50 \mathrm{~mm}$
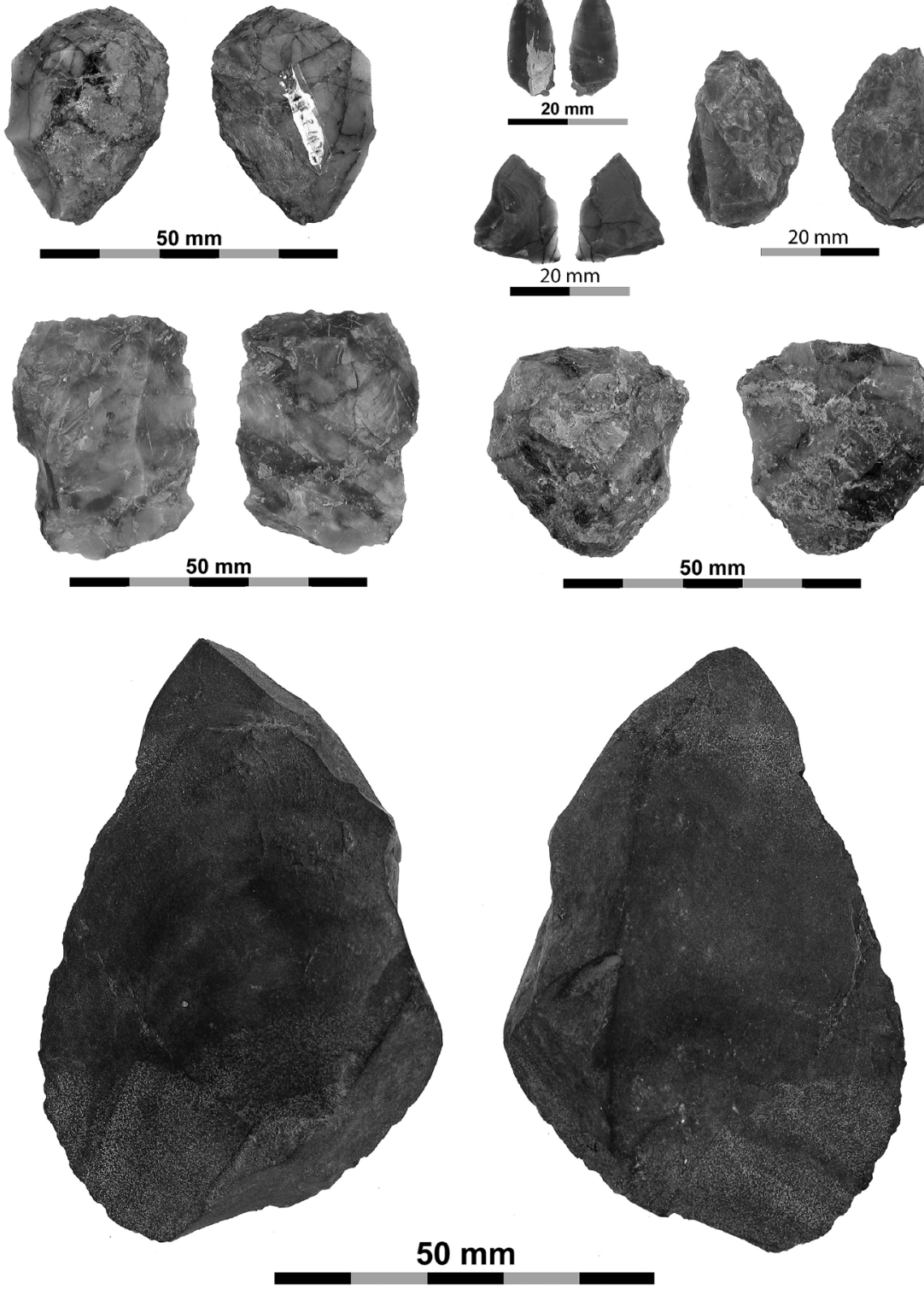

Fig. 8. Upper Palaeolithic artifacts from Ille Cave.

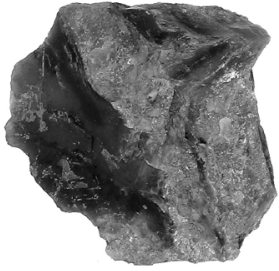

$50 \mathrm{~mm}$
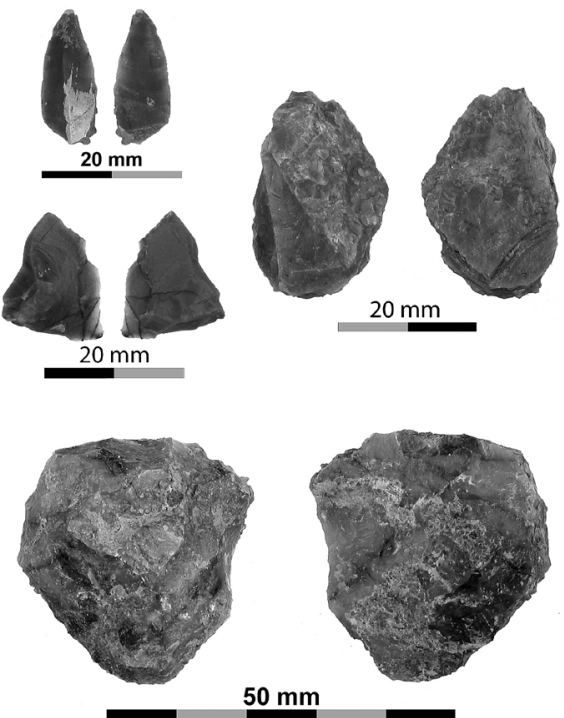

$0 \mathrm{~mm}$ 


\section{DETECTING MODERN TRAITS WITH MICROWEAR ANALYSIS}

Clues and traces of modern behavioral traits could be discovered with microwear analysis. This method allows the determination of stone tool use and function and reconstructs prehistoric technology and behavior (Keeley 1974; Semenov 1964; Tringham et al. 1974). It applies basic physical principles of interacting surfaces in relative motion to study the wear and tear created during such interactions between a working tool and the worked object (Yamada 1993). Experiments have demonstrated that almost any kind of contact, even with softer materials, will result in wear traces on the stone tool (Anderson et al. 1993; Beyries 1988; Kamminga 1979; Keeley 1980; Keeley and Newcomer 1977; Odell 1981; Pawlik 1992; Unrath et al. 1986; Vaughan 1985; and many others). The effects are the same for modern as for prehistoric tools made of stone (usually chert or flint).

Information on specific prehistoric activities concerning working and worked materials is imperative for microwear analysis. Fundamental research in microwear analysis is analogy-based using archaeological and ethnographic accounts and experimentation (Semenov 1964). An extensive framework of experiments replicating prehistoric tasks and activities and using replicas of stone tools on all kinds of possible working materials under close monitoring builds up the basic data pool that enables the analyst to interpret wear patterns on prehistoric stone tools. Although a large number of experiments and their results have been published in detail, the microwear analyst needs to conduct experiments to become acquainted with the effects and patterns of wear formation and learn to recognize wear traces on archaeological artifacts.

Two main categories of use-wear are relevant for analysis: edge damage patterns such as scarring or rounding of edges, usually observed under relatively low magnification using stereo-microscopes; and so-called "micropolishes," higher-reflecting altered areas on the microtopography of a stone tool, visible under high magnification using modified metallurgical reflected-light microscopes. Micropolishes can develop diagnostic features that allow the identification of specific contact materials (Keeley 1980; Vaughan 1985). Along with the detection of wear patterns, residues of the contact material adhering to stone tool surfaces are sometimes found, allowing direct evidence of the origin and nature of the worked material and activities conducted by tool users (e.g., Anderson 1980; Christensen et al. 1992; Dinnis et al. 2009; Fullagar 1998; Hardy and Garufi 1998; Kealhofer et al. 1999; Pawlik 1995, 2004b, 2004c; Rots 2003; Rots and Williamson 2004; Torrence and Barton 2006).

As a member of the Palawan Island Palaeolithic Research Project (Paz et al. 2006, 2008), this author has been conducting microwear analysis of selected Neolithic materials and Upper Palaeolithic flaked artifacts from the Ille Cave since 2006 (Pawlik 2006). Although they appear as mostly irregularly shaped flakes made of rather inferior raw materials such as andesite and heavily fissured radiolarite, they carry use-wear features that may indicate the presence of modern traits and complex behavior. Analogous to the wear traces on artifacts from Tabon and Minori Caves already mentioned, preliminary results show traces on the Ille assemblage of working harder organic materials such as bone, antler, wood, and bamboo (Fig. 9: artifact No. 37101; Fig. 10: No. 40408; Fig. 11: No. 41809). Even more characteristic of modern behavior are traces from working shell (Fig. 12: No. 35569).

Processing hide, an activity considered modern at least for the Sahul and western Pacific region (Gilligan 2010; Mellars 2005 : 22), was observed on artifact No. 41763 


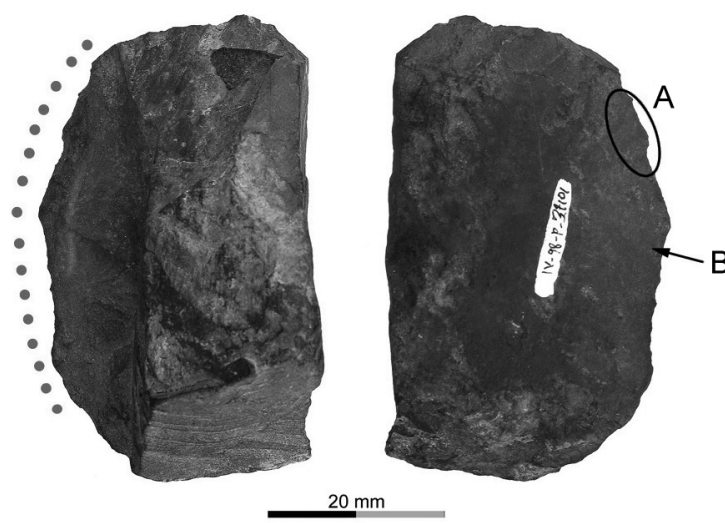

Ille No. 37101

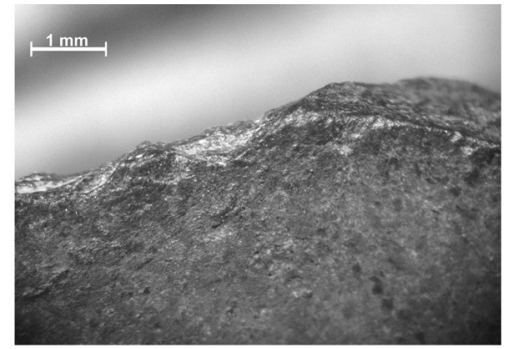

A

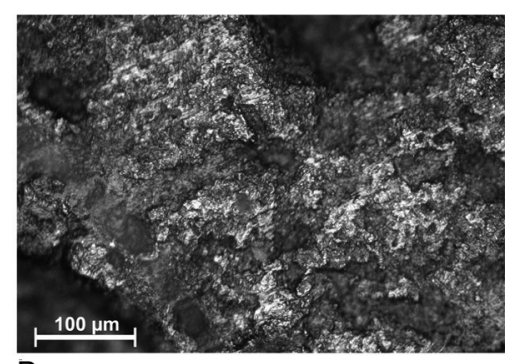

B

Fig. 9. Artifact No. 37101: Flake used as side scraper for working harder organic material. Indicated are the working area and locations of microphotos taken. A: abraded working edge; B: use polish and striations from working harder organic material.

(Fig. 13). The application of pigments such as red ochre to artifacts is also considered a modern trait. On an endscraper-like flake, traces of red pigment appear in combination with hide working (Fig. 14: No. 41713). Although it cannot be stated with absolute certainty whether the pigment stains are directly associated with hide processing or if they resulted from a different activity, the use of red ochre as coloring or tanning agent for skins and leather in the Palaeolithic has been frequently observed in microwear analyses (e.g., Büller 1988; Juel Jensen 1988; Pawlik 1995; van Gijn 1989; Vaughan 1985; Wadley et al. 2004).

The surfaces of several artifacts from Ille Cave carry so-called bright spots (Figs. $10 \mathrm{C}, 11 \mathrm{C})$. They are commonly seen as the result of non-intentional, repetitive rubbing contact between siliceous artifacts, such as when carried together in a pouch for some time (Levi-Sala 1996; Unrath et al. 1986). The appearance of such traces can, therefore, be interpreted as signs of curation, the process reflecting a tool's actual use relative to its maximum potential use (Andrefsky 2008). This can be seen as evidence of advanced behavior contrary to the "use-once-and-discard" expedient technology model (Mijares 2002).

Impact scars with hinge- and step-terminations on a triangular flake, as seen in artifact No. 40406 (Fig. 15A, B), suggest use as a projectile implement (Fischer et al. 1984; Lombard 2005; Lombard and Pargeter 2008). This is also a possible interpretation of the polish spots on the tip, which shows longitudinal striations on elevated parts of the microtopography on both faces (Fig. 15C, D). The interior surface of the base displays polishes that are not use-related but do conform to what is expected from minor movements of a tool against its haft (Cahen et al. 1979:681). The blackish residues appearing with these polishes are obviously remains of organic resin used as 

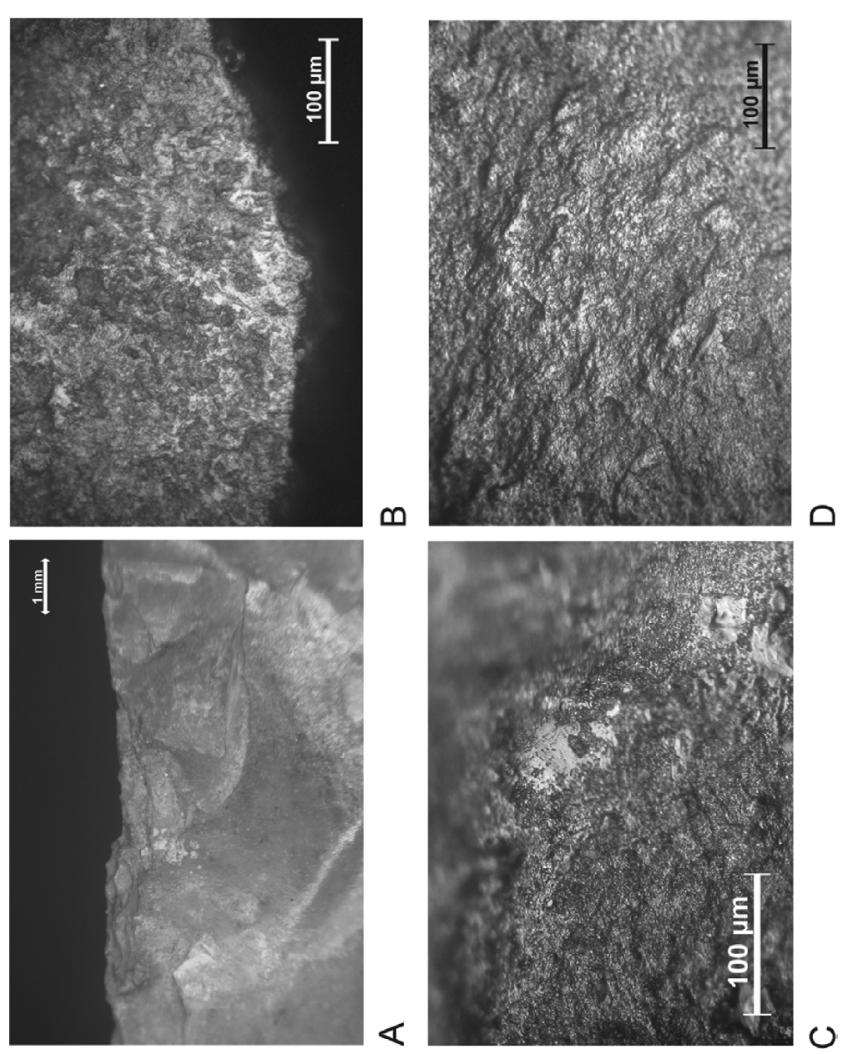

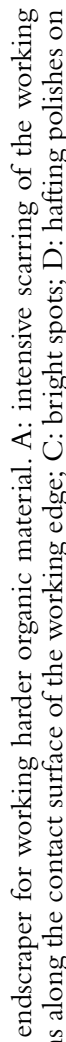

$\approx$
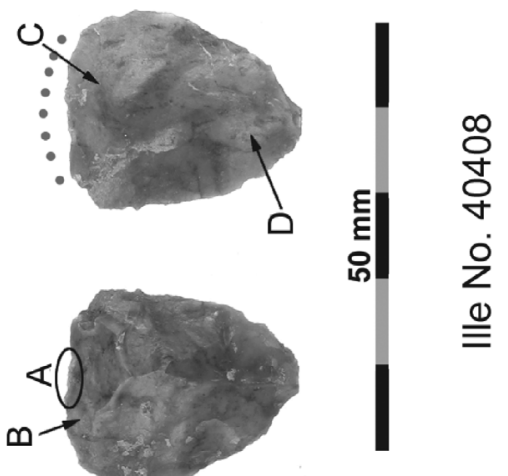

总

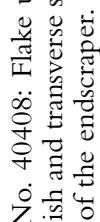

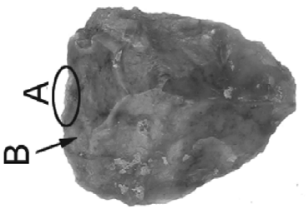

$\infty$
+े
oे
ㅇ
$\stackrel{0}{=}$

乙言荡

过壳芯

$\circ \ddot{\sim}$ 希

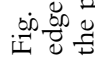



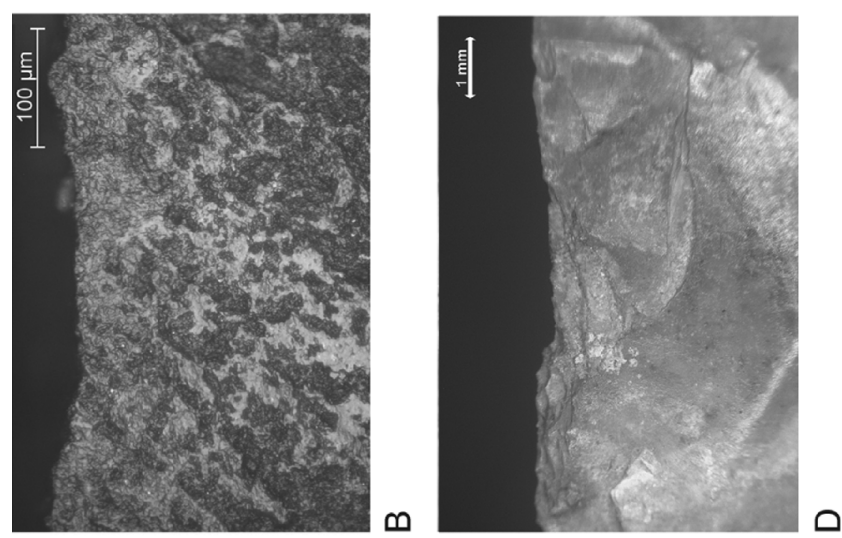

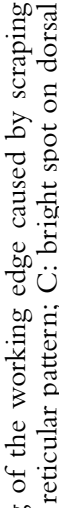
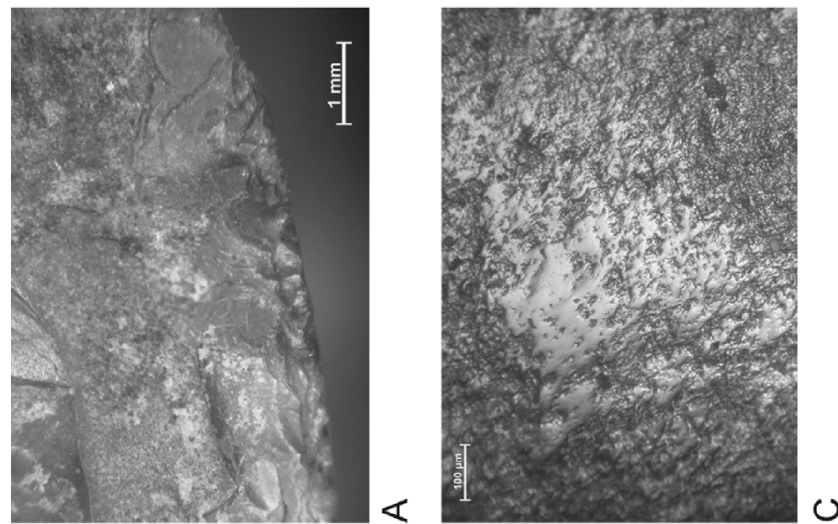

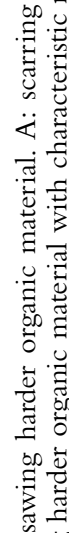

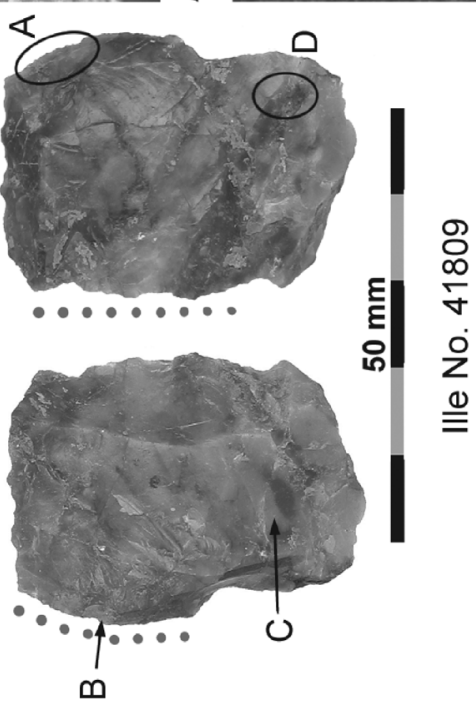

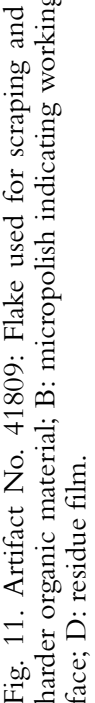



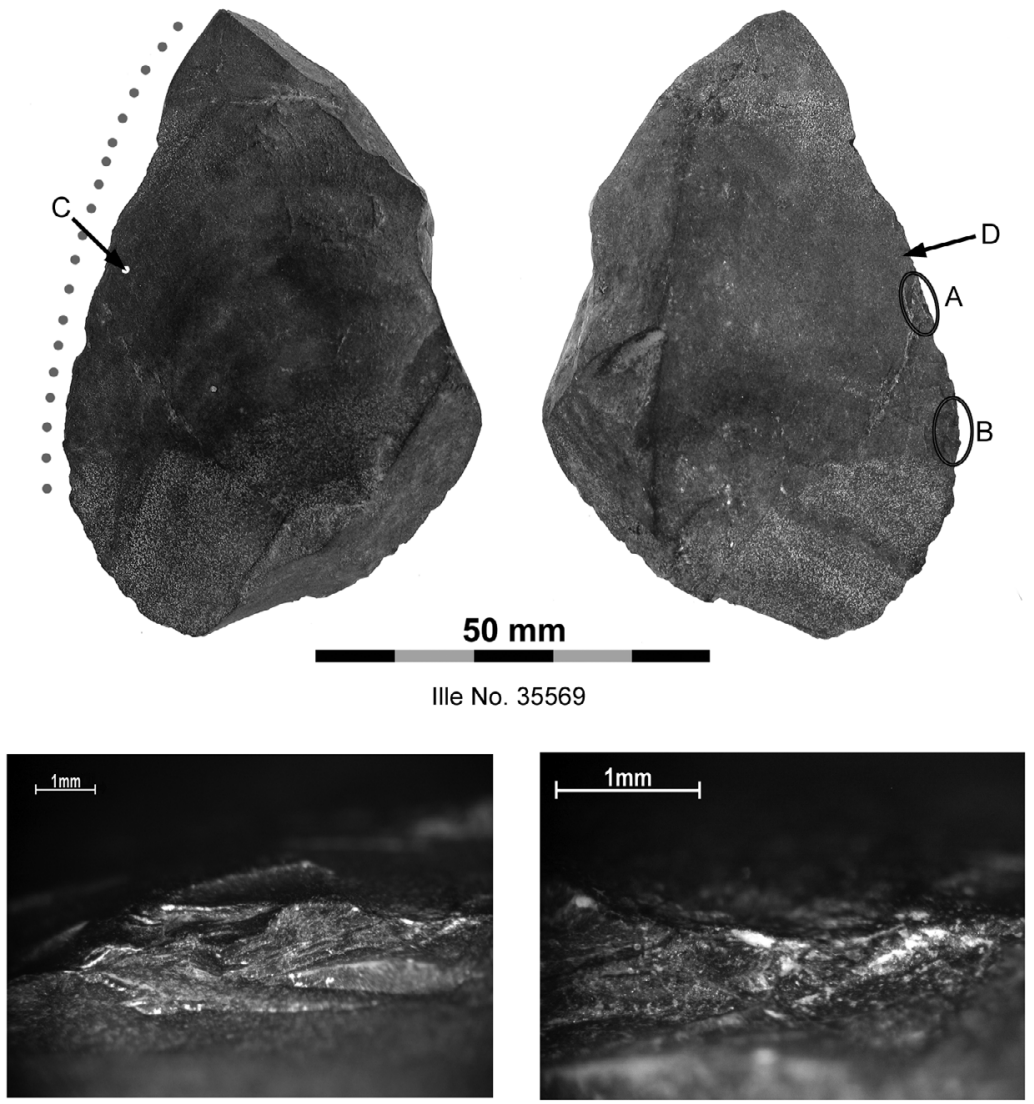

A

B
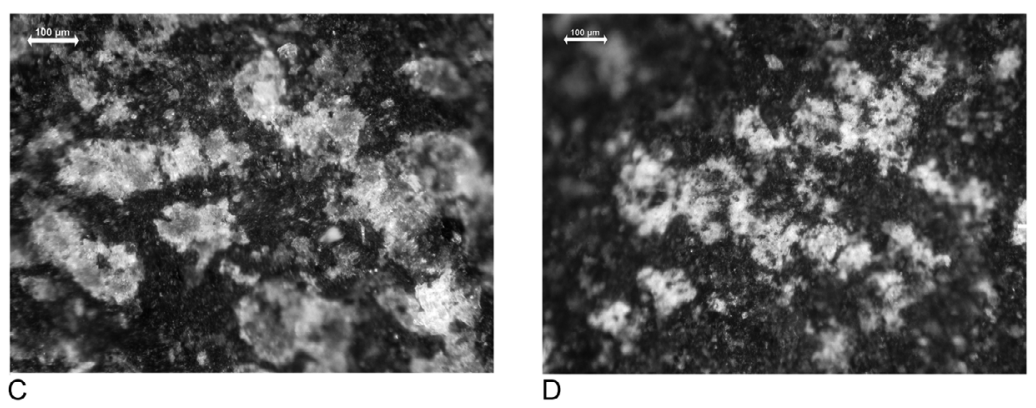

Fig. 12. Artifact No. 35569: Relatively large flake used for shell working. A: heavily worn and scarred working edge; B: shell residues on use-scars; C: high power microphoto of scattered particles of shell on the dorsal face of the working edge; D: high power microphoto of scattered particles of shell on the ventral face of the working edge. 


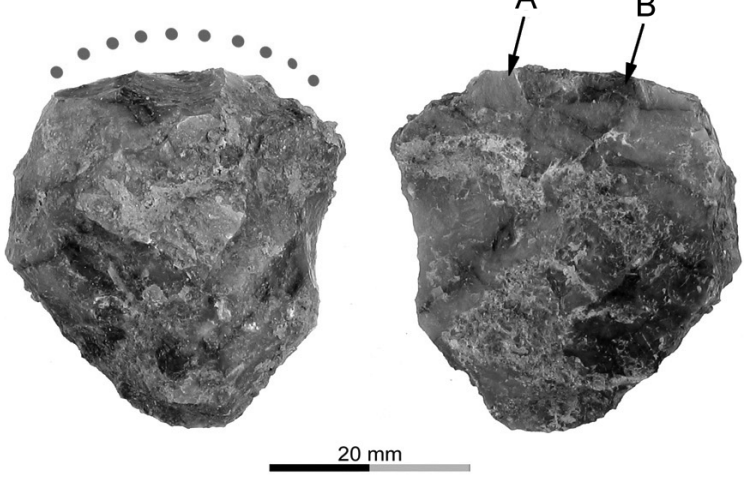

Ille No. 41763

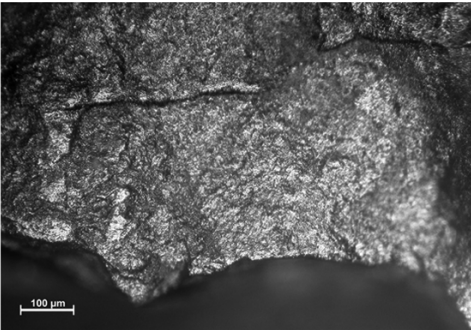

A

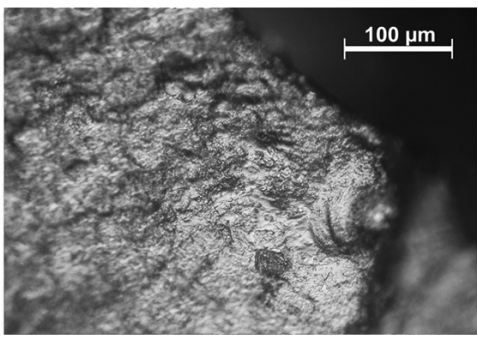

B

Fig. 13. Artifact No. 41763: Flake used for hide processing. A: rounded working edge and transversely oriented micropolish; B: extensive micropolish and surface abrasion caused by scraping hide.

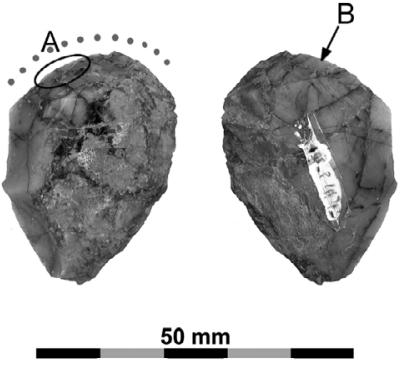

Ille No. 41713
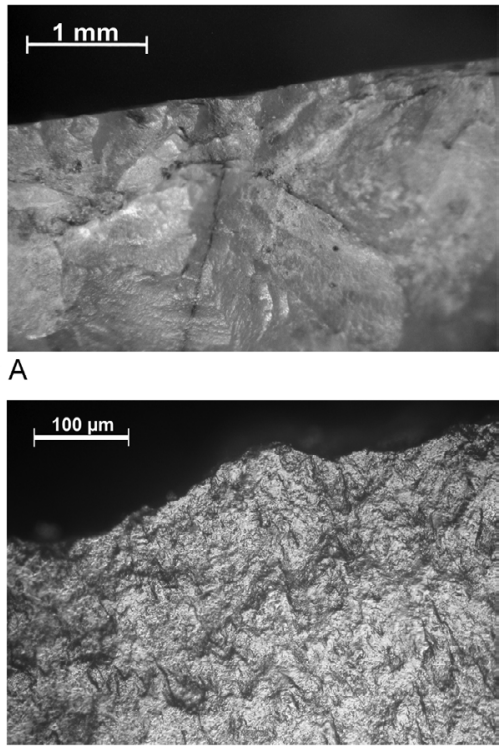

B

Fig. 14. Artifact No. 41713: Endscraper-like flake used for hide processing. A: residues of red-ochre on the working edge; B: extensive micropolish caused by working hide. 


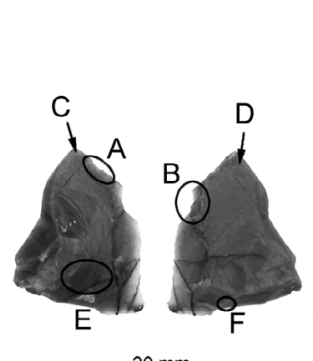

Ille No. 40406

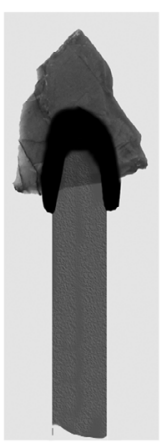

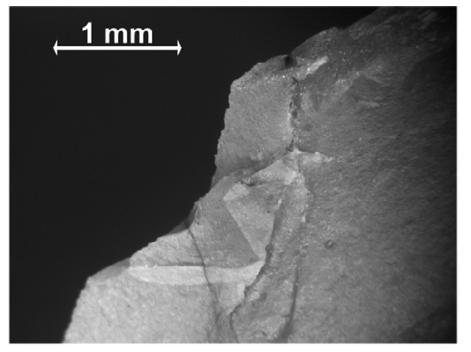

A

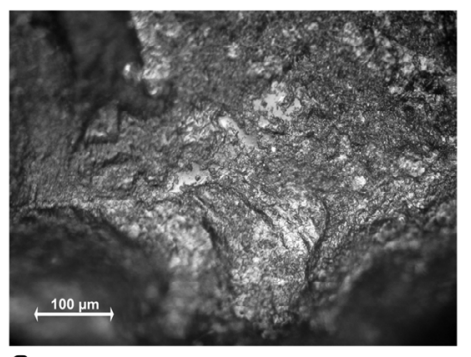

C

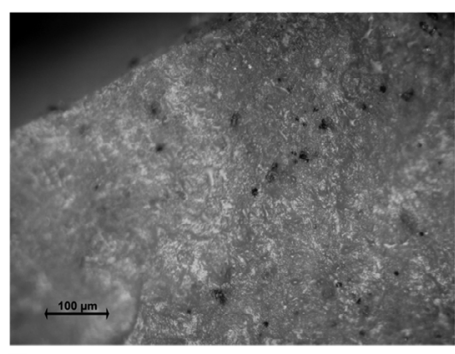

$\mathrm{E}$

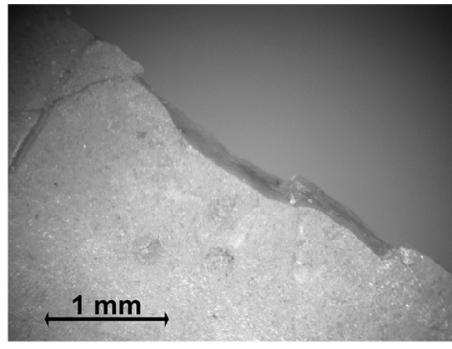

B

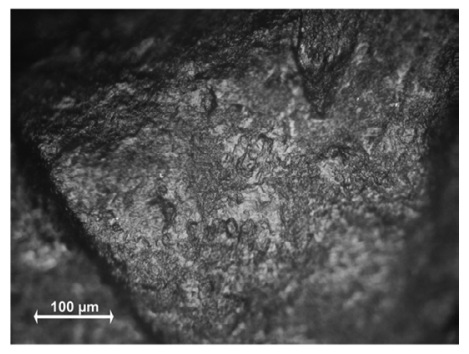

$\mathrm{D}$

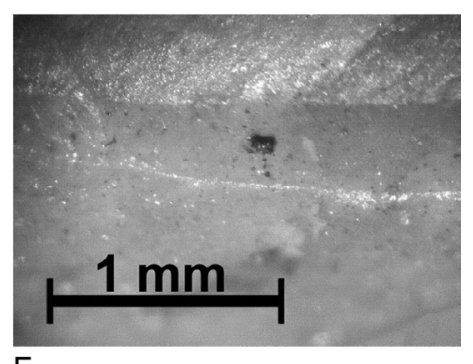

$\mathrm{F}$

Fig. 15. Artifact No. 40406: Triangular flake used as projectile point. A: impact scar near the tip; B: lateral impact scar; C: longitudinally oriented polish spots and striations on the dorsal tip; D: longitudinally oriented polish spots and striations on the ventral tip; E: blackish residues of organic hafting mastic on the dorsal base; F: blackish residues of organic hafting mastic on the ventral base.

hafting mastic (Fig. 15E, F). The drop-shaped endscraper No. 40408 similarly exhibits characteristic hafting polishes on its proximal part (Fig. 10D), while a blackish-reddish residue film appears along the lateral edge of No. 41809, also indicating hafting (Fig. 11D).

The combination of wear, hafting traces, and residues is quite remarkable. It identifies the artifacts as hafted armatures that were attached to shafts and fixed with resinous glue. This kind of adhesive appears very similar to resin residues found on projectile points made of bone and stingray spine from the west mouth of Niah Cave in Borneo, dated to 11,700-10,690 B.P. (Barton et al. 2009). The resins have been identified as deriving from Shorea spp., Agathis spp., or Canarium spp. These trees and their resins are common in the Philippines and Palawan. The resins have been used as appliqués on shell disk beads found in the Neolithic layers of Ille Cave as well (Basilia 2011). Shorea resin appears to be especially suitable for hafting purposes. It becomes soft when heated above $75^{\circ} \mathrm{C}$, which makes it an ideal binding material for retooling processes and replacing worn-out implements (Tschirch and Glimmann 
1896). While the specialized bone points from Niah provide further proof of the availability of a Late Pleistocene hafting technology in insular Southeast Asia, the use of unretouched lithic flakes as hafted implements for multicomponent tools and projectiles at Ille Cave is unique. It points to a technological concept beyond traditional morphological and typological models and reflects the constructive memory of the tool makers and their ability to perform complex sequences of action (Ambrose 2010).

Microwear analysis of artifacts from Ille Cave delivered the first evidence of hafted tools and projectile points, composite-tool making, and complex tool design in the Philippine Palaeolithic. Hafted composite tools and the making of hafting mastic for fixing lithic armatures in wooden shafts have been observed in European Micoquien and Aurignacien assemblages (Dinnis et al. 2009; Pawlik and Thissen 2008, 2011). They are considered components of the European and African package (Ambrose 2010; Deacon 2000; Keeley 1982; Wurz 1999). They are also regarded as a significant trait of behavioral modernity for Southeast Asia and the western Pacific region (Barton et al. 2009). However, hafting traces are easily overlooked or neglected in microwear analysis (Cahen et al. 1979; Keeley 1982). This analysis of relatively simple flakes from the Philippine Upper Palaeolithic showed that some were actually hafted armatures and parts of more complex composite tools. The small size of the flakes that predominate in Philippine lithic assemblages could even indicate that the toolmakers intended to use them as hafted implements (Pawlik 2009a).

This result presents a different perspective on the debate over whether wood and bamboo industries compensated for formal tools and lithic typologies in Southeast Asia. Considering bamboo and wood as prime materials for the manufacture of shafts for composite tools, rather than as replacements for stone tools, sheds new light on the dilemma of missing types in Southeast Asia's Palaeolithic and Epipalaeolithic (Haidle and Pawlik 2009).

\section{CONCLUSION}

The microwear study of the lithic artifacts from Ille Cave indicates that components of the package of modern behavioral traits were present in the Upper Palaeolithic of the Philippine archipelago. It also demonstrates that traditional methods of typological and technological research are sometimes insufficient in recognizing modern traits; additional analytic tools are needed. Microwear analysis offers technical and functional characterizations of lithic artifacts, identification of working and hunting tools, and determination of activities and site functions. It has no regional and chronological limitations but has the potential for detection of differentiated "modern" behaviors such as hafting and composite tool making, curation, fabrication of ornaments, shellfishing, use of pigments, and other complex technologies such as projectile points. Modern traits that seemed absent in the lithic record become visible with a closer look.

\section{ACKNOWLEDGMENTS}

The author is thankful to the University of the Philippines and its Office of the Vice Chancellor for Research and Development who supported this work with a research grant. Many thanks go to the Archaeological Studies Program and the members of the Palawan Island Palaeohistory Project for providing the author with the latest information and data on the ongoing fieldwork at El Nido. I would also like to thank Miriam N. Haidle (Heidelberg Academy of Science) and Philip Piper (Australian National University) for commenting on early drafts of this article. 


\section{REFERENCES CITED}

Ambrose, Stanley H.

2010 Coevolution of composite-tool technology, constructive memory, and language. Implications for the evolution of modern human behavior. Current Anthropology 51, Supplement 1:135147.

Anderson, Patricia

1980 A testimony of prehistoric tasks: Diagnostic residues on stone tool working edges. World Archaeology 12(2): 81-194.

Anderson, Patricia, Sylvie Beyries, Marcel Otte, and Hugues Plisson, eds.

1993 Traces et Fonction: Les Gestes Retrouvés. Actes du Colloque International de Liège, Etudes et Recherches Archéologiques de l'Université de Liège (ERAUL), Vol. 50.

ANDREFSKY, WILLIAM

2008 Lithic Technology: Measures of Production, Use, and Curation. Cambridge: Cambridge University Press.

Archaeological Studies Program

2007 The 2007 season of the Palawan Island Palaeolithic Research Project. A Partial report. Unpublished manuscript, Archaeological Studies Program, University of the Philippines.

Barker, Graham, Huw Barton, Michael Bird, Patrick Daly, ipoi Datan, Alan Dykes, Lucy Farr, David Gilbertson, Barbara Harrisson, Chris Hunt, Tom Higham, Lisa Kealhofer, John Krigbaum, Helen Lewis, Sue Mclaren, Alistair Pike, Phil Piper, Brian Pyatt, Ryan Rabett, Tim Reynolds, Jim Rose, Garry Rushworth, Mark Stephens, Chris Stringer, Jill Thompson, and Chris Turney

2007 The human revolution in lowland tropical Southeast Asia: The antiquity and behavior of anatomically modern humans at Niah Cave (Sarawak, Borneo). Journal of Human Evolution 52(3) : 243-261.

Barton, Huw, Philip J. Piper, Ryan Rabett, and Ian Reeds

2009 Composite hunting technologies from the Terminal Pleistocene and Early Holocene, Niah Cave, Borneo. Journal of Archaeological Science 36:1708-1714.

BAR-YOSEF, OFER

2002 The Upper Palaeolithic revolution. Annual Review of Anthropology 31:363-393.

Basilia, Pauline A.

2011 Morphological and Technological Analysis of the Cut Shell Beads from Ille Cave, El Nido, Palawan. Master's thesis, University of the Philippines, Archaeological Studies Program.

Bautista, Angel, and Jon de Vos

2002 Archaeological Exploration and Excavation at Solana, Cagayan. Unpublished manuscript. National Museum of the Philippines, Manila.

Bellwood, Peter

1997 Prehistory of the Indo-Malaysian Archipelago. Honolulu: University of Hawai'i Press.

Beyer, H. OtLey

1947 Outline review of Philippine Archaeology by islands and province. Philippine Journal of Science 77(3-4).

Beyries, Sylvie, ED.

1988 Industries Lithiques: Tracéologie et Technologie. British Archaeological Reports International Series No. 411.

BONDOC, Nestor H.

1979 A Re-investigation of the Espinosa Archaeological Sites: Cagayan and Kalinga-Apayao. Anthropological Papers No. 6. Manila: National Museum of the Philippines Publications.

Bräuer, GÜNTER, ANd Fred H. Smith, eds.

1992 Continuity or Replacement: Controversies in Homo Sapiens Evolution. Rotterdam: A. A. Balkema.

Brumm, Adam, and Michael W. Moore

2005 Symbolic revolutions and the Australian archaeological record. Cambridge Archaeological Journal $15: 157-175$.

BüLlER, JOCHEN

1988 Handling, hafting and ochre stains, in Industries Lithiques: Traceologie et Technologie: 5-46, ed. S. Beyries. British Archaeological Reports International Series 411, vol. 1. 
Cahen, Daniel, Lawrence H. Keeley, and Frederic van Noten

1979 Stone tools, toolkits and human behavior in prehistory. Current Anthropology 20(4) : 661-682.

CAYron, Jun

1999 Report on the Archaeological Survey and Exploration in Barangay New Ibajay, El Nido, Palawan. Hukay, Journal of the Archaeological Studies Program 2, No. 1.

Charoenwongsa, Pisit

1988 The current status of prehistoric research in Thailand, in Prehistoric Studies: The Stone and Metal Ages in Thailand: 17-41, ed. P. Charoenwongsa and B. Bronson. Papers in Thai Antiquity, vol. 1. Bangkok.

Christensen, Marianne, Philip Walter, and Michel Menu

1992 Usewear characterisation of prehistoric flints with IBA. Nuclear Instruments and Methods in Physics Research B 64:488-493.

Clottes, Jean (ed.)

2001 La Grotte Chauvet: l'art des origines. Paris: Seuil.

Conard, Nicholas J.

2003 Palaeolithic ivory sculptures from southwestern Germany and the origin of figurative art. Nature 426:830-832.

2008 A critical view of the evidence for a southern African origin of behavioural modernity. South African Archaeological Society Goodwin Series 10:175-179.

CONARD, Nicholas J., ED.

2006 When Neanderthals and Modern Humans Met. Tübingen: Kerns Verlag.

Conard, Nicholas J., Maria Malina, Susanne Münzel, and Friedrich Seeberger

2004 Eine Mammutelfenbeinflöte aus dem Aurignacien des Geissenklösterle: Neue Belege für eine Musiktradition im frühen Jungpaläolithikum auf der Schwäbischen Alb. Archäologisches Korrespondenzblatt $34: 447-462$.

Deacon, Hilary J.

2000 Modern human emergence: An African archaeological perspective, in Humanity from African Naissance to Coming Millennia: Colloquia in Human Biology and Palaeoanthropology: 217-226, ed. P. V. Tobias, M. A. Raath, J. Maggi-Cecchi, and G. A. Doyle. Florence: Florence University Press.

DENNELL, RoBIN W.

2009 The Palaeolithic Settlement of Asia. Cambridge: Cambridge University Press.

D'Errico, Francisco

2003 The invisible frontier. A multiple species model for the origin of behavioral modernity. Evolutionary Anthropology 12:188-202.

DÉTroit, Florent

2002 Origine et évolution des Homo sapiens en Asie du Sud-Est: Descriptions et analyses morphométriques de nouveaux fossiles. PhD diss., Muséum National d'Histoire Naturelle, Paris, France.

Détroit, Florent, Eusebio Z. Dizon, Christophe Falguères, Sébastien Hameau, Francois Sémah, AND WilfRedo RoNQUillo

2004 Upper Pleistocene Homo sapiens from Tabon cave (Palawan, the Philippines). Human Paleontology and Prehistory 3:705-712.

DibBle, Harold

1989 The implications of stone tool types for the presence of language during the Lower and Middle Palaeolithic, in The Human Revolution: Behavioral and Biological Perspectives on the Origins of Modern Humans: 416-432, ed. P. Mellars and C. Stringer. Princeton: Princeton University Press.

Dinnis, Robert, Alfred Pawlik, and Claire Gaillard

2009 Bladelet cores as weapon tips? Hafting residue identification and micro-wear analysis of three carinated burins from Les Vachons. Journal of Archaeological Science 36:1922-1934.

Dizon, Eusebio Z., Florent Détroit, Francois Sémah, Christophe Falguk̀res, Sébastien

Hameau, Wilfredo P. Ronquillo, and Emmanuel Cabanis

2002 Notes on the morphology and age of the Tabon Cave fossil Homo sapiens. Current Anthropology $43: 660-666$.

Dizon, Eusebio Z., And Alfred Pawlik

2010 The Lower Palaeolithic record in the Philippines. Quaternary International 223-224:444-450. 
Fischer, Anders, Peter Vemming Hansen, and Peter Rasmussen

1984 Macro and micro wear traces on lithic projectile points: Experimental results and prehistoric examples. Journal of Danish Archaeology 3:19-46.

Fox, Robert B.

1970 The Tabon Caves. Monograph of the National Museum of the Philippines, No. 1. Manila.

1978 The Philippine Palaeolithic, in Early Palaeolithic in South and East Asia: 59-85, ed. F. IkawaSmith. Paris: Moutton.

Fullagar, Richard, ED.

1998 A Closer Look. Recent Australian Studies of Stone Tools. Sydney University Archaeological Methods Series 6.

Gilligan, IAN

2010 The prehistoric development of clothing: Archaeological implications of a thermal model. Journal of Archaeological Method and Theory 17:15-80.

Habgood, Philip J., and Natalie R. Franklin

2008 The revolution that didn't arrive: A review of Pleistocene Sahul. Journal of Human Evolution $55: 187-222$.

HaHn, JOACHim

1986 Kraft und Aggression: Die Botschaft der Eiszeitkunst im Aurignacien Süddeutschlands? Tübingen: Archaeologica Venatoria.

Haidle, Miriam N.

2006 Menschen-Denken-Objekte. Zur Problem-Lösung-Distanz als Kognitionsaspekt im Werkzeugverhalten von Tieren und im Laufe der menschlichen Evolution. Habilitation thesis, University of Tübingen.

2008 Kognitive und kulturelle Evolution. Erwägen Wissen Ethik (EWE) 19(2):149-159.

Haidle, Miriam N., and Alfred F. Pawlik

2009 Missing types: Overcoming the typology dilemma of lithic archaeology in Southeast Asia. Bulletin of the Indo-Pacific Prehistoric Association 29:2-5.

2010 Pleistocene modernity: An exclusively Afro-European issue? Bulletin of the Indo-Pacific Prehistoric Association 30:3-8.

Hardy, Bruce L., and Gary T. Garufi

1998 Identification of woodworking on stone tools through residue and use-wear analyses: Experimental results. Journal of Archaeological Science 25(2) : 177-185.

Henshilwood, Christopher S., Francesco d’Errico, Royden Yates, Zenobia Jacobs, Chantal Tribolo, Geoff Duller, Norbert Mercier, Judith C. Sealy, Helene Valladas, Ian Watts, and ANN WinTLE

2002 The emergence of modern human behaviour: Middle Stone Age engravings from South Africa. Science 295: 1278-1280.

Henshilwood, Christopher S., and Curtis W. Marean

2003 The origin of modern behaviour: Critique of the models and their test implications. Current Anthropology 44(5): 627-651.

Jelinek, Arthur J.

1982 The Middle Pleistocene in the Southern Levant, with comments on the appearance of modern Homo sapiens. British Archaeological Reports 151 :57-101.

Johnson, Cara R., and Sally McBrearty

2010500,000 year old blades from the Kapthurin Formation, Kenya. Journal of Human Evolution 58:193-200.

Juel Jensen, Helle

1988 Functional analysis of prehistoric flint tools by high power microscopy: A review of West European literature. Journal of World Prehistory 2(1): 53-88.

KAMMINGA, JoHAN

1979 The nature of use-polish and abrasive smoothing on stone tools, in Lithic Use Wear Analysis: 143-157, ed. B. Hayden. New York: Academic Press.

Kealhofer, Lewis, Robin Torrence, and Richard Fullagar

1999 Integrating phytoliths within use-wear/residue studies of stone tools. Journal of Archaeological Science 26:527-546. 
Keeley, Lawrence H.

1974 Technique and methodology in microwear studies: A critical review. World Archaeology $5: 323-$ 336.

1980 Experimental Determination of Stone Tool Uses. Chicago: University of Chicago Press.

1982 Hafting and retooling: Effects in the archaeological record. American Antiquity 47:798809 .

Keeley, Lawrence H., and Mark H. Newcomer

1977 Microwear analysis of experimental flint tools: A test case. Journal of Archaeological Science $4: 29-62$.

KLEIN, RiChARD G.

1995 Anatomy, behavior, and modern human origins. Journal of World Prehistorica 9:167-198.

1999 The Human Career: Human Biological and Cultural Origins. Chicago: University of Chicago Press.

2003 Whither the Neanderthals? Science 299:1525-1527.

Klein, Richard G., and E. Blake

2002 The Dawn of Human Culture. New York: John Wiley and Sons.

KRESS, JONATHAN

1979 Tom Harrison, north Borneo, and Palawan: A preliminary assessment. Asian Perspectives 20(1) : 75-86.

LeVi-Sala, Irene

1996 A study of microscopic polish on flint implements. British Archaeological Reports Series 629.

LOMBARD, MarLize

2005 A method for identifying Stone Age hunting tools. South African Archaeological Bulletin 60(182): 115-120

Lombard, Marlize, and Justin Pargeter

2008 Hunting with Howiesons Poort segments: Pilot experimental study and the functional interpretation of archaeological tools. Journal of Archaeological Science 35:2523-2531.

McBrearty, Sally, and Alison Brooks

2000 The revolution that wasn't: A new interpretation of the origin of modern human behavior. Journal of Human Evolution 39: 453-563.

McBrearty, Sally, and Chris Stringer

2007 The coast in colour. Nature 449:793-794.

Mellars, Paul

1989a Archaeology and the population-dispersal hypothesis of modern human origins in Europe, in The Origin of Modern Humans and the Impact of Chronometric Dating: 196-216, ed. M. J. Aitken, C. Stringer, and P. Mellars. Princeton: Princeton University Press.

1989 bajor issues in the emergence of modern humans. Current Anthropology 30:349-385.

1991 Cognitive changes and the emergence of modern humans in Europe. Cambridge Archaeological Journal $1: 63-76$.

2005 The impossible coincidence. A single-species model for the origins of modern human behaviour in Europe. Evolutionary Anthropology 14:12-27.

2006 Going east: New genetic and archaeological perspectives on the modern human colonization of Eurasia. Science 313:796-800.

Mijares, Armand

2002 The Minori Cave Expedient Lithic Technology. Quezon City: Contributions to Archaeology Series, University of the Philippines Press.

2004 Lithic analysis of recently excavated Tabon Cave flakes. Proceedings of the Society of Philippine Archaeologists 2:15-19.

2005 The Archaeology of Peñablanca Cave Sites, Northern Luzon, Philippines. Journal of Austronesian Studies 1(2): 65-93.

2008 The Peñablanca flake tools: An unchanging technology? Hukay, Journal for Archaeological Research in Asia and the Pacific 12:13-34.

Mijares, Armand, Florent Détroit, Philip Piper, Rainer Grün, Peter Bellwood, Maxime Aubert, Guillaume Champion, Nida Cuevas, Alexandra De Leon, and Eusebio Dizon

2010 New evidence for a 67,000-year-old human presence at Callao Cave, Luzon, Philippines. Journal of Human Evolution 59: 123-132. 
Mithen, Steve

1996 The Prehistory of the Mind: A Search for the Origins of Art, Religion and Science. London: Thames and Hudson.

MOSER, JOHANNES

2001 Hoabinhian: Geographie und Chronologie eines steinzeitlichen Technokomplexes in Südostasien. Bonn: AVA-Forschungen 6.

NARR, KARL

1966 Die frühe und mittlere Altsteinzeit Süd- und Ostasiens. Bern: Handbuch für Urgeschichte.

Neri, LeEe A.

2002 Obsidian Sourcing at Huluga Open Site: An Evidence of Exchange? Master's thesis, University of the Philippines.

2005 Obsidian from the Huluga site and its implications. Hukay, Journal of the University of the Philippines Archaeological Studies Program 7:55-67.

Odell, George H.

1981 The mechanics of use-breakage of stone tools: Some testable hypotheses. Journal of Field Archaeology 8: 197-209.

Patole-Edoumba, Elise

2002 L'industrie Lithique Préhistorique de Débitage des Philippines de la Fin du Pleistocène à l'Holocène Moyen. PhD thesis, University of Aix-Marseille I.

2009 A Typo-Technological Definition of Tabonian Industries. Bulletin of the Indo-Pacific Prehistoric Association 29:21-25.

PAwLIK, Alfred

1992 Mikrogebrauchsspurenanalyse, Methoden-Forschungsstand-Neue Ergebnisse. Urgeschichtliche Materialhefte 9. Tübingen: Archaeologica Venatoria.

1995 Die mikroskopische Analyse von Steingeräten. Experimente-AuswertungsmethodenArtefaktanalysen. Tübingen: Urgeschichtliche Materialhefte 10. Archaeologica Venatoria.

2002 Is there an Early Palaeolithic in the Philippines? New approaches for lithic analysis in the Philippines, in Australasian Connections and New Directions: Proceedings of the 7th Australasian Archaeometry Conference: 255-270, ed. M. Horrocks and P. Sheppard. Research in Anthropology and Linguistics, vol. 5. Auckland, New Zealand: University of Auckland.

2004a The Palaeolithic site of Arubo 1 in central Luzon, Philippines. Bulletin of the Indo-Pacific Prehistoric Association $24: 3-12$.

$2004 b$ Identification of hafting traces and residues by scanning electron microscopes and energydispersive analysis of X-rays, in Lithics in Action: Papers from the Conference Lithic Studies in the Year 2000: 172-183, ed. Elizabeth A. Walker, Francis Wenban-Smith, and Frances Healy. Oxford: Lithic Studies Society Occasional Paper 8, Oxbow Books.

2004c An early Bronze Age pocket lighter, in Lithics in Action: Papers from the Conference Lithic Studies in the Year 2000: 149-151, ed. Elizabeth A. Walker, Francis Wenban-Smith, and Frances Healy. Oxford: Lithic Studies Society Occasional Paper 8, Oxbow Books.

2006 Analysis of polished stone adzes from Ille Cave at El Nido, Palawan Island, Philippines. Hukay, Journal of the University of the Philippines Archaeological Studies Program 10:38-59.

$2009 a$ Is the functional approach helpful to overcome the typology dilemma of lithic archaeology in Southeast Asia? Bulletin of the Indo-Pacific Prehistoric Association 29:6-14.

$2009 b$ Morphological and Functional Analysis of Lithic Assemblages from the Pleistocene Layers of Ille Cave, Dewil Valley, El Nido, Palawan. A Progress Report. Unpublished manuscript, University of the Philippines, Archaeological Studies Program.

Pawlik, Alfred, and Wilfredo P. Ronquillo

2003 The Palaeolithic in the Philippines. Lithic Technology 28(2): 79-93.

Pawlik, Alfred, And Jürgen Thissen

2008 Birkenpechgewinnung und Rentierjagd im Indetal. Archäologie im Rheinland 2007, 4144.

2011 Hafted armatures and multi-component tool design at the Micoquien site of Inden-Altdorf, Germany. Journal of Archaeological Science 38:1699-1708.

Paz, Victor, Helen lewis, Myra lara, Huw Barton, Philip Piper, Janine Ochoa, Timothy Vitales, Jane Carlos, Thomas Higham, Lee Neri, Vito Hernandez, Janelle Stevenson, Emil Robles, Andrea Ragrario, Robin Padilla, Wilhelm G. Solheim II, and Wilfredo Ronquillo

2008 Terminal Pleistocene to mid-Holocene occupation and an early cremation burial at Ille Cave, Philippines. Antiquity 82(316):318-335. 
Paz, Victor, Helen Lewis, and Wilfredo Ronquillo

2006 Report on the Palawan Island Palaeolithic Research Project for 2006. Unpublished manuscript, University of the Philippines, Archaeological Studies Program.

Piper, Philip J., Frederliza Z. Campos, and Hsiao-Chung Hung

2009 A study of the animal bones recovered from Pits 9 and 10 at the site of Nagsabaran in northern Luzon, Philippines. Hukay, Journal for Archaeological Research in Asia and the Pacific 14:4790 .

POOKAJORN, SURIN

1988 Archaeological Research of the Hoabinhian Culture or Technocomplex and its Comparison with Ethnoarchaeology of the Phi Tong Luang, a Hunter-Gatherer Group of Thailand. Tübingen: Archaeological Venatoria 9.

Pope, Geoffrey C.

1989 Bamboo and human evolution. Natural History (October) : 1-15.

RONQUillo, WILFREDO P.

1981 The Technological and Functional Analyses of Lithic Flake Tools from Rabel Cave, Northern Luzon, Philippines. Anthropological Papers No. 13, National Museum, Manila.

Ronquillo, Wilfredo P., Rey Santiago, Shijun Asato, and Kazuhiko Tanaka

1993 The 1992 re-excavation of the Balobok Rockshelter, Sanga Sanga, Tawi Tawi Province, Philippines. Journal of the Historiographical Institute Okinawa 18:1-40.

ROTS, VERLE

2003 Towards an understanding of hafting: The macro- and microscopic evidence. Antiquity $77: 805-815$.

Rots, Verle, and Bonny S. Williamson

2004 Microwear and residue analyses in perspective: The contribution of ethnoarchaeological evidence. Journal of Archaeological Science 31:1287-1299.

Schick, Kathy D., AND Dong Zhuan

1993 Early Paleolithic of China and Eastern Asia. Evolutionary Anthropology 2(1) :22-35.

SCHMidT, PATRICK

2008 Characterization and geological provenance of jasper that was used for debitages in the archaeological Site of Tabon Cave, Philippines. Hukay, Journal for Archaeological Research in Asia and the Pacific $14: 3-12$.

Semenov, Sergej A.

1964 Prehistoric Technology. Bath, England: Adams and Dart.

Shutler, Richard, and Mark Mathisen

1979 Pleistocene studies in the Cagayan Valley of Northern Luzon, Philippines. Journal of the Hong Kong Archaeological Society 8: 105-114.

Solheim, Wilhelm G., II

1970 Prehistoric archaeology in eastern mainland Southeast Asia and the Philippines. Asian Perspectives $13: 47-58$.

Szabó, KATHERINE

2005 Technique and Practice: Shell-working in the Western Pacific and Island Southeast Asia. PhD diss., The Australian National University, Canberra.

Szabó, Katherine, Marie Swete Kelly, and Antonio Peñalosa

2004 Preliminary results from excavations in the eastern mouth of Ille Cave, northern Palawan, in Southeast Asian Archaeology. Festschrift for Wilhelm G. Solheim II: 209-224, ed. Victor Paz. Diliman: University of the Philippines Press.

Torrence, Robin, and Huw Barton, eds.

2006 Ancient Starch Research. Los Angeles: Left Coast Press.

Tringham, Ruth, Glenn Cooper, George H. Odell, Barbara Voytek, and Anne Whitman

1974 Experimentation in the formation of edge damage: A new approach to lithic analysis. Journal of Field Archaeology $1: 171-196$.

Tschirch, Alexander, and Gustav Glimmann

1896 Archiv der Pharmazie, Vol. 234, Issue 8:585-589. 
Tulang, Catherine S.

2000 A Functional Analysis of the Reported "Small Flake and Blade" Industry from Duyong Cave, Palawan, Philippines. Unpublished manuscript. Archaeological Studies Program, University of the Philippines.

Unrath, Günther, Linda R. Owen, Annelou van Gijn, Emily H. Moss, Hugues Plisson, and Patrick Vaughan

1986 An evaluation of use-wear studies: A multi-analyst approach. Early Man News 9/10/11:117175. Tübingen: Archaeologica Venatoria.

Van Gijn, Annelou L.

1989 The Wear and Tear of Flint. Leiden: Analecta Prehistorica Leidensia 22.

VAughan, Patrick

1985 Use-wear Analysis of Flaked Stone Tools. Tucson: University of Arizona Press.

von Koenigswald, G. H. Ralf

1958 Preliminary report on a newly discovered Stone Age culture from Northern Luzon, Philippine Islands. Asian Perspectives 2:69-71.

Wadley, Lyn, Bonny Williamson, and Marlize Lombard

2004 Ochre in hafting in Middle Stone Age southern Africa: A practical role. Antiquity 78:661-675.

Wurz, SARAH

1999 The Howiesons Poort at Klasies River: An argument for symbolic behaviour. South African Archaeological Bulletin 54:38-50.

Xhauflair, Hermine

2009 Analyse tracéologique et recherche de résidus: Contribution à l'étude de l'industrie lithique de Tabon Cave, Palawan, Philippines. Master's thesis, Muséum National d'Histoire Naturelle, Paris.

YAMADA, SHOH

1993 The formation process of "use-wear polishes," in Traces et Fonction: Les Gestes Retrouves: 433-446, ed. Patricia Anderson, Sylvie Beyries, Marcel Otte, and Hugues Plisson. Actes du colloque international de Liège, Etudes et Recherches Archéologiques de l'Université de Liège (ERAUL) 50.

ZILHÃO, JỗO

2001 Anatomically Archaic, Behaviorally Modern: The Last Neanderthals and their Destiny. Amsterdam: Stichting Nederlands Museum voor Anthropologie en Praehistoriae. Joh. Enschede.

\begin{abstract}
Behavioral modernity has been a widely neglected topic for Southeast Asia's prehistory. Evidence of modern packages or even traits is basically absent in the Palaeolithic assemblages. This absence has considerably influenced the discussion of hominid behavior and their cultural and cognitive abilities. In a case study on terminal Pleistocene artifacts from Ille Cave on Palawan Island, indications of the presence of several items of the modern trait list, foremost the first evidence of hafted lithic tools and the use of adhesives in the Philippine Palaeolithic, were detected through microwear analysis. The results showed that unretouched and morphologically less characteristic flaked artifacts often considered as mere expedient tools could have served as hafted armatures of multicomponent tools. For the ongoing discussion on the development and expansion of modern behavior, methods like microwear analysis can eliminate some limitations of traditional technological and morphological analysis of lithic assemblages. KEYwORDs: Lithic technology, microwear analysis, composite tools, behavioral modernity, Palaeolithic, Philippines.
\end{abstract}

